\title{
Floyd Bloom Discusses the Messengers of the Mind
}

\author{
(D)Teresa Esch
}

DOI:http://dx.doi.org/10.1523/ENEURO.0076-14.2014

Science Writer, Society for Neuroscience

Key words: acetylcholine; monoamines; neurotransmitters; norepinephrine

\section{Significance Statement}

Some of the basic principles of nervous system function that we now take for granted were once topics of great controversy that required decades of research to resolve. One such principle is that neurons communicate via chemicals. In the "History of Neuroscience" lecture at this year's meeting of the Society for Neuroscience, Floyd Bloom discussed how this principle came to be accepted by the community. In doing so, he hoped to recognize some of the great minds who contributed to the debate and also to remind young scientists that even great minds can sometimes be wrong. This commentary presents some of the key discoveries highlighted in his talk.

The ability of plant alkaloids and animal venoms to affect nervous system function has been known for millennia. People throughout the world have taken advantage of these effects to paralyze prey, kill enemies, keep alert, and enter spiritual states. But an understanding of how neuroactive chemicals work-by affecting synaptic transmission-came about only gradually, beginning in the 19th century. As is often the case, many long-held beliefs had to be overturned before this understanding was reached. In his "History of Neuroscience" lecture at this year's meeting of the Society for Neuroscience, Floyd Bloom described some of the paradigm shifts that were necessary for people to appreciate chemical neurotransmission and "the messengers of the mind."

Bloom reckoned that the journey began in 1844, with Claude Bernard's studies of curare. Bernard first administered curare to a living frog. Dissecting the frog immediately after it died, he found that the heart was still beating and muscles still contracted when stimulated electrically. From

Received December 24, 2014; accepted December 24, 2014; First published December 31, 2014.

Correspondence should be addressed to Teresa Esch, 2307 Rosedown Drive, Reston, VA 20191. E-mail: tesch@alumni.virginia.edu.

DOI:http://dx.doi.org/10.1523/ENEURO.0076-14.2014

Copyright (C) 2014 Esch

This is an open-access article distributed under the terms of the Creative Commons Attribution License Attribution-Noncommercial 4.0 International which permits noncommercial reuse provided that the original work is properly attributed. this he concluded that curare paralyzed the frog by poisoning the nerves rather than the muscles (Black, 1999). Subsequent experiments on isolated nerve-muscle preparations revealed that if only the nerve was bathed in curare, nerve stimulation continued to cause muscle contraction, whereas if only the muscle was bathed in curare, nerve stimulation did not evoke contraction; yet the curare-bathed muscle contracted if stimulated directly (Bennett, 2001). At that time it was believed that vital spirits flowed through hollow nerve tubes and inflated muscles, causing them to contract. Therefore, Bernard concluded that curare disconnects motor nerves from their cell bodies in the spinal cord.

Of course we now know that nerves do not work by pumping vital spirits into muscles. This is largely thanks to the work of Emil du Bois-Reymond, who studied the electrical properties of tissues. He proposed that nerve cells stimulate muscles electrically, but he acknowledged that they might instead use chemicals. For this, du Bois-Reymond is credited with being the first to propose chemical neurotransmission.

The next step in the journey was led by John Newport Langley, starting in 1885. By using nicotine to stimulate sympathetic ganglia, Langley was able to map the major pathways of what he named the autonomic nervous system. He went on to use physiological, pharmacological, and anatomical techniques to investigate synapses in the sympathetic nervous system. With his student Thomas Elliott, he found that extracts from the adrenal medulla mimicked the 
effects of sympathetic nerve stimulation on smooth muscles. He noted, however, that not all cells responded to the extracts, leading him to hypothesize that "receptive substances" present on a cell determined its responsiveness (Langley, 1905).

Another student of Langley's was Charles Sherrington, with whom he investigated the effects of cortical lesions on dogs (Nobel Media, 2014). But Sherrington eventually turned his attention to the spinal cord. That nerve stimulation sometimes caused muscles to relax had been known for some time, but the mechanism was generally assumed to be peripheral. By tracing the afferent and efferent pathways between muscles and the spinal cord, Sherrington developed the theory of reciprocal innervation, which tied contraction of a flexor to relaxation of the antagonistic extensor muscle via interneurons in the spinal cord. Central to this theory was the novel hypothesis that there are two types of neurons: excitatory and inhibitory (Sherrington, 1932).

One of Sherrington's early influences was Ramon y Cajal, whom Sherrington first met in Spain while studying the cholera outbreak (Nobel Media, 2014). When Cajal later sent his work describing Golgi staining of the developing nervous system to the Royal Society, the work was passed to Sherrington. Sherrington thus became an early supporter of the neuron doctrine, i.e., that the nervous system is composed of individual cells rather than being a continuous reticulum. The eventual universal acceptance of the neuron doctrine led inevitably to the question of how neurons communicate.

Following on the ideas of du Bois-Reymond, many prominent neuroscientists of the day-including John Eccles, Lorente de Nó, Herbert Gasser, and Ralph Gerard-believed that neurons communicated electrically. They thought that the actions of chemicals were too slow to mediate the rapid effects of neurotransmission. But Thomas Elliott, a student of John Langley's, suggested in 1905 that epinephrine might be released by sympathetic nerves (Elliott, 1905). This hypothesis arose from his studies of the effects of adrenalin/epinephrine on the sympathetic nervous system.

Elliott's suggestion was largely ignored by the scientific community, including Langley and even Elliott himself in subsequent articles (Rubin, 2007). But in studying the actions of synthetic biogenic amines, Henry Dale provided more evidence that a catecholamine mediated the effects of sympathetic nerves on their target muscles. Dale also discovered that acetylcholine, which he isolated from ergot fungus, mimicked the effects of parasympathetic nerve stimulation on smooth muscle and its effects were likewise blocked by atropine (Rubin, 2007). But because the compounds he studied were exogenous, their role as endogenous neurotransmitters remained in doubt.

Direct evidence for chemical neurotransmission was first published by Otto Loewi in 1921. Performing an experiment that came to him in his sleep (Rubin, 2007), Loewi stimulated the vagus nerve innervating a frog's heart; this slowed the heartbeat. He then transferred the Ringer's solution surrounding the vagus nerve and heart to another heart. This slowed the second heart, indicating that the vagus nerve released a transferrable substance, which Loewi called "Vagusstoff" (Loewi, 1936). Attempts to replicate the experiment failed for several years because-it was later discovered- the release of acetylcholine (which Vagusstoff was eventually shown to be) varies across species and seasons and is degraded by acetylcholinesterase in the blood. Thus, chemical neurotransmission remained a controversial hypothesis.

John Eccles was one scientist who persisted in the belief that neurons communicated electrically, not chemically (Eccles, 1948). His mind remained unchanged until after the advent of electrophysiological techniques during World War II. Using such techniques, Stephen Kuffler and Bernard Katz showed that denervated muscle was sensitive to acetylcholine and that acetylcholine mimicked the effects of motor nerve stimulation. (Hunt and Kuffler, 1950). This convinced Eccles that chemical neurotransmission occurred at the neuromuscular junction. Nevertheless, he continued to believe that communication between neurons within the CNS was strictly electrical. This changed when a central feature of his electrical model to explain Sherrington's reciprocal inhibition was disproved. According to his hypothesis, a motor neuron would be depolarized by input from antagonist muscles. But intracellular recordings showed that the neuron was hyperpolarized, thus disproving the model and leading Eccles to finally accept that chemical neurotransmission occurs in the CNS (Eccles et al. 1954).

The universal acceptance of chemical neurotransmission led naturally to the quest to identify other neurotransmitters. In 1958, W.D. Paton published an article in Annual Reviews of Physiology (Paton, 1958) outlining criteria for defining a substance as a neurotransmitter. First, the chemical had to be present in neurons. Second, the chemical had to be released upon nerve stimulation. Third, application of the chemical to the neuron's target cell had to replicate the effect of nerve stimulation. And fourth, antagonists that blocked the effect of the chemical must also block the effect of nerve stimulation.

It was around this time that Floyd Bloom went to NIMH to escape the doctor's draft. His first objective was to provide support for the catecholamine hypothesis of depression by showing that norepinephrine (NE) was a neurotransmitter. He began his studies in the hypothalamus, which was known to contain high levels of NE. Using five-barrel micropipettes that allowed simultaneous electrical recording and application of chemical substances, he found that one-third of neurons responded to NE by spiking faster, one-third responded by spiking more slowly, and the remainder did not respond at all (Bloom et al., 1963). This prompted him to look exclusively at neurons that receive nerve fibers containing NE.

He first attempted to identify noradrenergic fibers using the formaldehyde condensation technique developed by Carlsson, Falck, and Hillarp (Carlsson et al. 1962). This technique, developed in Sweden, allowed the visualization of monoaminergic pathways; however, Bloom found that it did not work well in the humid air of Washington, D.C. He therefore turned to a technique developed by Julius Axelrod, examining the uptake of tritiated NE by nerve cells. One of the brain areas found to be innervated by NE fibers was the cerebellum, whose cellular connectivity and characteristic neuron types were well described by the extensive work of Eccles and Ito. Therefore, Bloom and his colleagues Barry Hoffer and George Siggins used five-barrel electrodes to record Purkinje cell responses (Siggins et al. 1969). They found that NE modified Purkinje cell activity through 
$\beta$-adrenergic receptors. Later, after other researchers discovered that the NE fibers innervating the cerebellum originated in the locus ceruleus, Bloom and colleagues stimulated that nucleus and demonstrated that it replicated all the effects of NE on Purkinje cells (Hoffer et al., 1973). Thus, they satisfied all the criteria for NE being a neurotransmitter in the CNS.

Meanwhile, other researchers had success using Falck and Hillarp's formaldehyde condensation technique to identify dopamine and serotonin as additional neurotransmitters in the CNS. Bernard Brodie then demonstrated that reserpine, which made rats act as if they were depressed, depletes the brain of serotonin (Brodie et al., 1966). This was one of the first steps in the development of biological psychology and psychoactive medication. The findings influenced Seymore Kety, who proposed the monoamine hypothesis of schizophrenia, mania, and depression in 1967 (Schildkraut and Kety, 1967). This work led to the idea that interference with any neurotransmitter, its transporters, or its receptors could be at the root of neuropsychiatric disease, and that targeting these elements could be the basis of therapy. Bloom noted that "I might have that tattooed on my chest because it is the credo that I have lived by throughout my career."

Later studies led to the discovery of ever more neurotransmitters. The discovery of opioid receptors by Sol Snyder (Snyder, 1975) led to the rapid discovery of endogenous opiates, including enkephalin and dynorphin. Asking what neurotransmitter pathway is responsible for the effects of cannabis led to the discovery of endocannabinoid receptors and the first lipid neurotransmitter, anandamide. We now know that many other kinds of molecules can be neurotransmitters: amino acids, ATP, adenosine, NO, hydrosulfides, etc. And there is growing evidence that glia can release molecules that affect neurotransmission. Throughout this period, new controversies emerged and were settled. Notably, it was initially concluded that peptides and amino acids could not be neurotransmitters, but we have since learned that this view was wrong.

Bloom concluded his lecture by asking what the history of neuroscience will look like in 10-15 years. Suppose we were able to map every pathway in the mammalian brain precisely, including the neurotransmitters secreted and the behavioral effects of each pathway's activity. Would we then understand the brain? Bloom thinks not. He believes that we need "to rise to a higher level of understanding," with a new symbolic language akin to mathematics or musical annotation. He asked the audience to consider "The Creation of Adam", the famous painting by Michelangelo on the ceiling of the Sistine Chapel. He noted that in the painting, God sits on a cloud that bears a striking resemblance to the human brain. In other words, he said, "God is in the human brain." He ended with a close-up of God's finger touching Adam's and asked the audience to "think about the possibility that this was the first synapse."

\section{References}

Bennett MR (2001) History of the synapse. London: Harwood Academic Publishers.

Black J (1999) Claude Bernard on the action of curare. BMJ 319: 622Medline

Bloom FE, Oliver AP, Salmoimghi GC (1963) The responsiveness of individual hypothalamic neurons to microelectrophoretically administered endogenous amines. Intern J Neuropharmacol 2:181193.CrossRef

Brodie BB, Comer MS, Costa E, Dlabac A (1966) The role of brain serotonin in the mechanism of the central action of reserpine. $J$ Pharmacol Exp Ther 152:340-349. Medline

Eccles JC (1948) Conduction and synaptic transmission in the nervous system. Annu Rev Physiol 10:93-116. CrossRef Medline

Eccles JC, Fatt P, Koketsu K (1954) Cholinergic and inhibitory synapses in a pathway from motor-axon collaterals to motoneurones. J Physiol 126:524-562. Medline

Elliott TR (1905) On the action of adrenalin. J Physiol 32:401-467.

Carlsson A, Falck B, Hillarp NA (1962) Cellular localization of brain monoamines. Acta Physiol Scand Suppl 56:1-28. Medline

Hoffer BJ, Siggins GR, Oliver AP, Bloom FE (1973) Activation of the pathway from locus coeruleus to rat cerebellar purkinje neurons: pharmacological evidence of noradrenergic central inhibition. $J$ Pharmacol Exp Ther 184:553-569. Medline

Hunt CC, Kuffler SW (1950) Pharmacology of the neuromuscular junction. Pharmacol Rev 2:96-120.

Langley JN (1905) On the reaction of cells and of nerve-endings to certain poisons, chiefly as regards the reaction of striated muscle to nicotine and to curari. J Physiol 33:374-413. Medline

Loewi O (1936) Nobel Lecture: "The Chemical Transmission of Nerve Action". Nobelprize.org. Nobel Media AB 2014. Web. 2 Dec 2014. http://www.nobelprize.org/nobel_prizes/medicine/laureates/1936/ loewi-lecture.html

Nobel Media AB (2014) Sir Charles Sherrington-Biographical. Nobelprize.org. http://www.nobelprize.org/nobel_prizes/medicine/ laureates/1932/sherrington-bio.html

Paton WD (1958) Central and synaptic transmission in the nervous system; pharmacological aspects. Annu Rev Physiol 20:431-470. CrossRef Medline

Rubin RP (2007) A brief history of great discoveries in pharmacology: in celebration of the centennial anniversary of the founding of the american society of pharmacology and experimental therapeutics. Pharmacol Rev 59:289-359. CrossRef Medline

Schildkraut JJ, Kety SS (1967) Biogenic amines and emotion. Science 156:21-37. Medline

Sherrington C (1932) Nobel Lecture: "Inhibition as a Coordinative Factor". Nobelprize.org. Nobel Media AB 2014. Web. 2 Dec 2014. http://www.nobelprize.org/nobel_prizes/medicine/laureates/1932/ sherrington-lecture.html

Siggins GR, Hoffer BJ, Bloom FE (1969) Cyclic adenosine monophosphate: possible mediator for norepinephrine effects on cerebellar purkinje cells. Science 165:1018-1020. Medline

Snyder SH (1975) The opiate receptor. Neurosci Res Program Bull. 13[Suppl]:1-27. Medline 